\title{
New from Praeger
}

\section{IN SEARCH OF SOUTHEAST ASIA: A Modern History}

David Joel Steinberg, David K. Wyatt, John R. W. Smail, Alexander Woodside, William R. Roff, David P.Chandler $\bullet$ Edited by David Joel Steinberg. This indispensible history of Southeast Asia examines the social, economic, political, and cultural dimensions of the region's transformation since the eighteenth century. 544 pp., 10 maps, appendixes, bibliog., index

$\$ 12.95$ (paper, \$5.95)

\section{HISTORY OF INDONESIA IN THE TWENTIETH CENTURY}

Bernhard Dahm - Translated by P. S. Falla. In this penetrating study, Bernhard Dahm analyzes the political, social, and economic forces that have shaped the Indonesia of today and provides new insights into the complex history of this pivotal Southeast Asian state. 320 pp., maps, 14 tables, bibliog., index

$\$ 10.00$

\section{CONFLICT IN LAOS: The Politics of Neutralization Revised and Enlarged Edition}

Arthur J. Dommen. In this greatly expanded revision of his 1964 classic, Arthur Dommen analyzes both the widening of the Southeast Asian conflict and the prospects for Laos in the 1970's. The Journal of Asian Studies praised the original edition as "valuable background reading for a comprehension of contemporary patterns of conflict in Southeast Asia." 460 pp., maps, 6 tables, 7 appendixes, bibliog., index $\$ 12.50$

\section{BANNER OF PEOPLE'S WAR, THE PARTY'S MILITARY LINE}

General Vo Nguyen Giap - Preface by Jean Lacouture - Introduction by Georges Boudarel. In these seven articles, which first appeared in North Vietnamese newspapers in December, 1969, General Giap sums up the experience of the North Vietnamese Army in its long struggle to control Vietnam. $128 \mathrm{pp}$., illus. $\quad \$ 5.50$

\section{THE UNITED STATES AND THE FUTURE OF THAILAND}

David A. Wilson. A newspaper correspondent and scholar in Thailand for six years, Professor Wilson views the stability of Thailand within the context of the cold war. He surveys the history and nature of the Thai-American alliance and the potential role of Thailand in Southeast Asia after the Vietnam war. 192 pp., maps, frontispiece, charts, 2 tables, bibliog., index

$\$ 7.50$

\section{MAN, STATE, AND SOCIETY IN CONTEMPORARY SOUTHEAST ASIA}

Edited by Robert O. Tilman. In this volume, more than thirty of the world's leading specialists focus on the changing societies of nine countries in postwar Southeast Asia. "A wide and carefully selected range of specialist articles. . . Most successful." -The Times Literary Supplement (London) 654 pp., 5 maps, 17 tables, 8 figs., bibliog., index

$\$ 13.50$ (paper, \$5.95)

PRAEGER PUBLISHERS • 111 Fourth Avenue, New York N.Y. 10003 


\section{THE NEW ZEALAND JOURNAL OF HISTORY}

\section{Editor: Keith Sinclair}

Published twice yearly by the University of Auckland.

Forthcoming articles:

W.E. Cheong 'The Beginnings of Credit Finance on the China Coast'

Michael C. Pugh 'The New Zealand Legion, 1932-35'

Henry Reynolds 'Australian Nationalism: Tasmanian Patriotism'

Peter Munz 'Non-European History'

Priscilla Williams 'New Zealand and the 1930 Imperial Conference'

Subscriptions (N.Z. $\$ 3.00$; A. $\$ 3.50$; U.S. $\$ 4.00 ; \$ 1.12 .6$ stg.) and requests for back copies should be addressed to:

The Business Manager

New Zealand Journal of History

History Department, University of Auckland

Private Bag

Auckland, New Zealand. 


\section{Southeast Aria}

An International Quarterly

Southeast Asia is a multi-disciplinary journal for scholars of all nationalities interested in Southeast Asia. As a matter of editorial policy, Southeast Asia will endeavor to present a broad spectrum of articles and views while avoiding commitment to particular political or ideological positions.

Although the Center for Vietnamese Studies at Southern Illinois University publishes Southeast Asia, editorial policy is governed by a Board of Editors and an International Editorial Advisory Board. The members of the Board of Editors are:

Wesley R. Fishel (Editor)

Michigan State University

Nguyen Dinh Hoa (Associate Editor)

Southern Illinois University

Hildred Geertz (Book Review Editor)

Princeton University

Robert O. Tilman

(Associate Book Review Editor)

Columbia University

John F. Cady

Ohio University

H. B. Jacobini

Southern Illinois University
Kenneth P. Landon

American University

Willis E. Malone

Southern Illinois University

Joel Maring

Southern Illinois University

Douglas S. Paauw

Wayne State University

Karl J. Pelzer

Yale University

Phan Thien Chau

Rider College

M. Ladd Thomas

Northern Illinois University

ARTICLES IN VOL. 1, NO. 1 ARE:

Charles A. Fisher

Guy J. Pauker

Michael Leifer

Fred R. von der Mehden

Frank C. Darling

Jay S. Salkin

Stephen Addiss
"A View of Southeast Asia"

"The Gestapu Affair of 1965: Change of Leadership in Indonesia"

"Peace and War in Cambodia"

"The Rise and Fall of the Religious State in Burma"

"Political Development in Thailand and the Philippines: A Comparative Analysis"

"Land Size and Patterns of Resource Productivity in Rice Production"

"The Theatre Music of Vietnam"

Southeast Asian Archives/Notes et Documents de l'Asie du Sud-est

"Dai-nam Chinh-bien Liệt-truyện Sơ-tạ, Nam-chương-truyen"

(Description of Luang Prabang) Translated and annotated by Sokichi Kimura

\section{ADDRESS:}

The Editor

SOUTHEAST ASIA, An International Quarterly Southern Illinois University Carbondale, Ill. 62901, U.S.A.

\section{SUBSCRIPTION RATES:}

US $\$ 5.00$ ( 6.00 overseas) Students 8.00 ( 9.00 overseas) Regular 15.00 (16.00 overseas) Libraries Equivalent in Yen, Pounds, Francs, and UNESCO Coupons accepted. 


\section{JOURNAL OF SOUTHEAST ASIAN STUDIES}

The Journal of Southeast Asian Studies, known until December 1969 as the Journal of Southeast Asian History, is published for the Department of History, University of Singapore by McGraw-Hill Far Eastern Publishers (S) Limited in March and September.

Articles in the Journal of Southeast Asian Studies do not represent the views of the Editors or those of the publisher. The Editor is responsible for the final selection of the content of the Journal and reserves the right to reject any material deemed inappropriate for publication. Responsibility for opinions expressed and for the accuracy of facts published in articles rests solely with the individual authors.

Requests for permission to reprint articles should be directed to the Editor. Articles appearing in this journal are abstracted and indexed in ABC POL SCI, HISTORICAL ABSTRACTS and/or AMERICA: HISTORY AND LIFE.

\section{CONTRIBUTIONS}

Contributions are invited from all scholars, especially those working in Southeast Asian universities and research institutions. The length of articles should preferably be between 4000 and 8000 words. Progress reports on research projects, notes on conferences, and comments on institutions devoted to Southeast Asian studies are also welcomed. All contributions should be typewritten or mimeographed, with double-spacing, and submitted in duplicate.

Each contributor will receive 30 offprints of his/her article and a complimentary copy of the Journal.

Editorial correspondence and contributions should be directed to

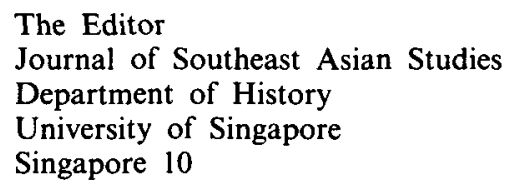

\section{Subscriptions}

Subscription rates are as follows:

Price: $\$ \$ 8.50$ per copy (by surface mail)

2nd class airmail add:
U.S.A.
$\$ \$ 8.50$ per copy
U.K./Europe
$\$ \$ 7.50$ per copy
Australia/N.Z.
\$\$5.00 per copy
S. America
S\$8.50 per copy
Africa
\$\$7.50 per copy
Asia
S\$5.00 per copy

Subscriptions and all business correspondence should be addressed to:

The Marketing Manager

McGraw-Hill Far Eastern Publishers (S) Ltd.

Jalan Boon Lay

Jurong

Singapore 22 


\section{CONTRIBUTORS TO THIS ISSUE}

NICHOLAS TARLING, Professor of History at the University of Auckland is a specialist in the history of the Malay Archipelago. His publications include British Policy in the Malay Peninsula and Archipelago, 1824-1871, Anglo-Dutch Rivalry in the Malay World, 1780-1824, Piracy and Politics in the Malay World, and A Concise History of Southeast 'Asia.'

W. DAVID MCINTYRE is Professor of History at the University of Canterbury, New Zealand. Principally concerned with the history and international relations of the Commonwealth countries, he is author of Colonies into Commonwealth. The Imperial Frontier in the Tropics, 1865-1875, and Neutralism, Non-Alignment and New Zealand.

KEITH JACKSON, Professor in the Department of Political Science, University of Canterbury, deals with New Zealand's domestic politics and foreign policies. A co-author of New Zealand Politics in Action, he has a forthcoming book entitled The Future and Abolition of the New Zealand Legislative Council.

J. D. B. MILLER, Professor of International Relations at the Australian National University, was for some years Editor of The Australian Outlook. He has published Australian Government and Politics. The Commonwealih in the World. The Nature of Politics, Britain and the Old Dominions, and The Politics of the Third World.

R. CATLEY is Lecturer in the Department of Politics, University of Adelaide and a graduate of the London School of Economics and the Australian National University.

T. B. MILLAR, Professorial Fellow in the Department of International Relations, Australian National University, has published books on Australia's Defence, The Commonwealth and the United States, and Australia's Foreign Policy.

J. L. S. GIRLING is Fellow in the Department of International Relations, Australian National University. His research interests cover the international relations of Southeast Asia, and United States policy in Asia. He has written articles on Vietnam, Thailand, and Cambodia.

C. G. F. SIMKIN, Professor of Economics, University of Sydney and one time ECAFE Consultant, has research interest in the contemporary trade of Asia. He is author of The Instability of a Dependent Economy, Economics at Large, and The Traditional Trade of Asia.

PETER JOHN BOYCE is Reader in Political Science at the University of Tasmania. Author of Malaysia and Singapore in International Diplomacy, he is interested in the diplomatic machinery and practice of new states. 